\title{
Proposed S.A.M.S. Therapy to Tackle the Coronavirus
}

\author{
Mister Seun Ayoade* \\ Physiology, Alumnus University of Ibadan College of Medicine, Nigeria
}

*Corresponding author: Mister Seun Ayoade BSc (Hons) Physiology, Independent Researcher, Alumnus University of Ibadan College of Medicine Oyo State Nigeria

\section{Opinion}

S.A.M.S. is an acronym for Seun Ayoade's Medical System [1], an alternative form of therapy based on the Germ Terrain Duality theory of disease. The Germ-Terrain duality theory of disease states that the etiology of certain diseases/diseased states is better explained as a complex interplay between germs and the inherent anatomical/physiological integrity of the body cells. It argues that the etiology of certain diseases is not fully explained merely by the presence of germs (Germ Theory) or by a mere loss of cellular integrity (Terrain Theory). As a result, the prevention and treatment of such diseases should focus not just on fighting germs but on maintaining/restoring the anatomical/physiological cellular integrity. The Germ-Terrain duality theory is a harmonization of the current Germ Theory (popularized by Louis Pasteur) and the hitherto discarded Terrain Theory (popularized by Pierre Bechamp) [2-3].

The coronavirus outbreak has taken thousands of lives away [4] and is causing global panic. The coronavirus menace seems to be validating the germ terrain duality theory of disease. For some reason, very few children are succumbing to the virus [5]. It seems the elderly are having the most fatalities. Like the previous SARS and MERS outbreaks, the very young seem to have some strange resistance. Since all people from newborn babies to the very old are being exposed to the same coronavirus but are having different infection, recovery and fatality rates it is obvious that whatever is causing this disparity is a function of the terrain. I hereby humbly wish to appeal to all those doctors and immunologists, pharmacologists etcetera furiously working on a cure/treatment/ vaccine for the coronavirus to look not only at the virus but the terrain. One terrain parameter present in babies but absent in large amounts in adults is the foetal haemoglobin, otherwise called
Haemoglobin F. Could the use of Haemoglobin F-such as is now being used to treat the sickle cell disease (e.g. via hydroxyurea)help adults resist the coronavirus? I do not have a medical degree, my degree is in physiology, but with my limited knowledge and in light of the fact that malaria and AIDS medicine is already being tried for treatment of the coronavirus [6-11], it should be no big stretch to try Haemoglobin F. Best of luck and good health to all!

\section{References}

1. Seun Ayoade (2019) Introducing SAMS. Adv Complement Alt Med 5(1).

2. Ayoade S (2017) Etiology, epidemiology and therapeutic history of malaria validate germ-terrain duality. Postulates there of J Mol Genet Med 11: 261

3. Mister SA (2017) Koch's postulates and germ terrain dualism; cellular dust as yet another term for microzymas. JOJ Nurse Health Care 5(4): 555-666.

4. https://www.worldometers.info/coronavirus/

5. https://www.washingtonpost.com/health/2020/03/10/coronavirusis-mysteriously-sparing-kids-killing-elderly-understanding-why-mayhelp-defeat-virus/

6. https://www.scientificamerican.com/article/to-fight-coronavirusoutbreak-doctors-deploy-drugs-targeting-hiv-malaria-and-ebola/

7. Steinberg (2003) Therapies to increase fetal hemoglobin in sickle cell disease. MH1.Boston University School of Medicine, Room E211, 88 East Newton Street, Boston, MA 02118, USA Curr Hematol Rep 2(2): 95-101.

8. https://en.wikipedia.org/wiki/Hereditary_persistence_of_fetal_ hemoglobin

9. https://www.sciencedirect.com/topics/nursing-and-healthprofessions/hemoglobin-f

10. Martin H Steinberg MD, FRCP, FRCPath, DSc, Swee Lay Thein MD (2000) Fetal hemoglobin (hemoglobin F) in health and disease.

11.https://www.urmc.rochester.edu/encyclopedia/content. aspx? contenttypeid $=167 \&$ contentid=hemoglobin_fetal 


\section{(c) (1) \\ This work is licensed under Creative Commons Attribution 4.0 License}

To Submit Your Article Click Here:

Submit Article

DOI: 10.32474/RRHOAJ.2020.05.000205

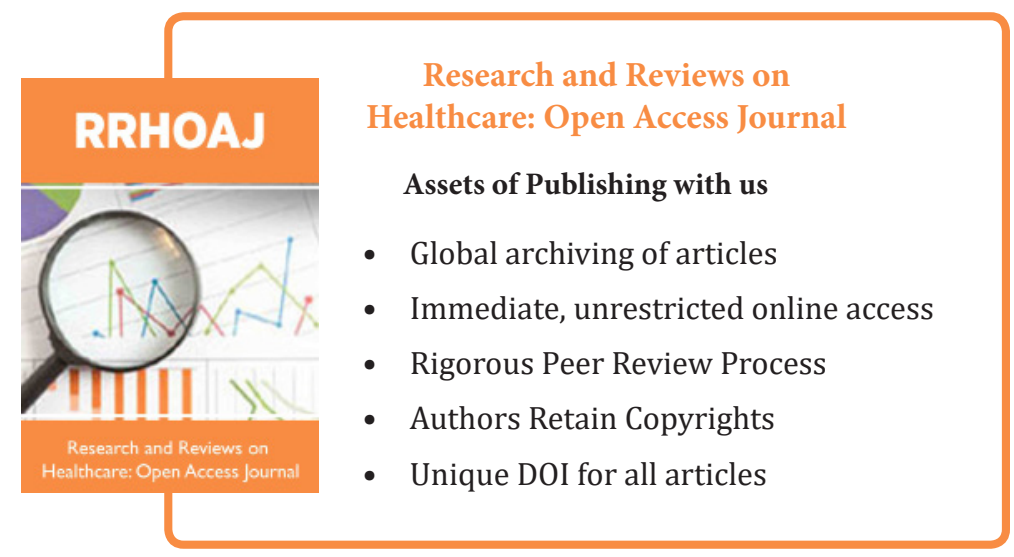

